\title{
CHEMICAL AND MICROBIOLOGICAL INDICATORS OF QUALITY IN A YELLOW OXISSOL UNDER CONVENTIONAL TILLAGE OF DIFFERENT AGES
}

\author{
INDICADORES MICROBIOLÓGICOS E QUÍMICOS DE QUALIDADE DE UM \\ LATOSSOLO AMARELO SOB MANEJO CONVENCIONAL EM DIFERENTES \\ IDADES
}

\author{
Leovânio Rodrigues BARBOSA ${ }^{1}$; Ademir Sérgio Ferreira de ARAÚJO²; \\ Francisco Rafael da SILVA ${ }^{2}$; Luís Alfredo Pinheiro Leal NUNES ${ }^{2}$; \\ Artenisa Cerqueira RODRIGUES ${ }^{2}$; Catharina Teixeira CORTEZ ${ }^{3}$; \\ Carlos Humberto Aires MATOS FILHO'
}

1. Universidade Federal da Paraíba, Areia, PB, Brasil; 2. Universidade Federal do Piauí, Teresina, PI, Brasil. luisalfredo@ufpi.edu.br; 3. Fundação Agente, Teresina, PI, Brasil.

\begin{abstract}
Brazil's agricultural production in Savanna soils has been highlighted due to significant yield gains in these areas. The present study aimed to evaluate changes in soil chemical and biological indicators of Piauí Savanna areas after 1 (PC1), 3 (PC3) and 6 (PC6) years under conventional tillage compared to a native Savanna forest (NF), used as control. Chemical ( $\mathrm{pH}, \mathrm{P}, \mathrm{Ca}^{2+}, \mathrm{Mg}^{2+}, \mathrm{K}^{+}, \mathrm{H}^{+}, \mathrm{Al}^{3+}$ and organic carbon) and total organic carbon (TOC) and microbiological attributes (microbial biomass carbon (MBC), basal respiration, microbial quotient and metabolic quotient), were assessed. In PC6 and PC3 areas, $\mathrm{Al}^{3+}, \mathrm{H}^{+}+\mathrm{Al}^{3+}$ and total organic carbon reduction and $\mathrm{pH}$ and nutrient content increase were observed in all layers evaluated. TOC was little influenced by time, since the change was gradual according to soil use. MBC and qMIC values were higher in the soil under natural vegetation, indicating adverse effects of

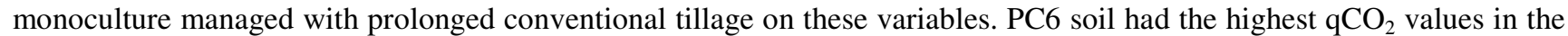
depths of 0 to 0.20 and 0.20 to $0.40 \mathrm{~m}$, which shows low efficiency of microorganisms in converting organic residue into microbial biomass in this system. Conventional management increased soil biological quality loss and favored chemical properties with its time of use.
\end{abstract}

KEYWORDS: Conventional tillage. Degradation. Soybean. Savanna.

\section{INTRODUCTION}

The Piauí state Savanna, considered by many as the last Brazilian agricultural frontier due to its favorable environmental conditions (latitude, altitude, rainfall, topography and soil), has been highlighted in Brazilan a high-potential region for grain production, such as corn, rice and especially soybean (PETTER et al., 2012). For the author, besides the characteristics previously mentioned, most of soils in the Savanna biome have proper clay and organic matter ratio, which may represent great cation exchange potential. Savanna soils are predominantly OXISSOL with great agriculture potential. The soil class aforementioned has fertility limitations, such as high acidity, low base saturation and high aluminum saturation (SOUZA; LOBATO, 2004), requiring fertilizer and corrective application to obtain good yields.

However, the introduction of agricultural systems substituting forests causes ecological imbalance, changing soil properties, whose intensity varies according to weather conditions, adopted use and management, and soil nature. Typically, constant use of soil management practices, such as conventional tillage by plowing and harrowing, contributes to disruption of aggregates. Thus, organic matter is exposed to decomposition, reducing nutrient cycling, decreasing soil organism quantity and diversity, and lowering crop yields in Savanna soils (LISBOA, et al., 2012; PORTO et al., 2009).

Chemical indicators show parameters that are responsible for natural processes of soil functioning, such as microbial biomass influence, and nutrient availability and content, among others (ARAGÃO et al., 2012). Chemical indicators are usually grouped into variables related to soil organic matter content, soil acidity, nutrient content, toxic elements and certain relationships, such as base and aluminum saturation (ARAÚJO et al., 2012). In turn, the use of microbiological indicators to evaluate soil quality has been considered appropriate. Microorganisms are the largest active fraction of organic matter. Therefore, they can be used to detect changes in organic matter level caused by plant management (MARCHIORI JUNIOR; MELO, 2000), prolonged monoculture 
(MATIAS et al., 2009) and the agricultural system adopted (BALLOTA et al., 1998).

This study was based on the hypothesis that the OXISSOL with the longest time of use would have higher macronutrient contents and better values of other chemical attributes used to assess soil fertility when compared to a soil with shorter time of use. On the other hand, conventional management increases soil biological quality loss with time. Given the above, this study aimed to detect changes in chemical and microbiological indicators of soil quality in areas under conventional management in soybean monocultures of different ages in relation to a native Savanna forest area.

\section{MATERIAL AND METHODS}

The study was conducted on Real farm, Regeneração County, Piauí State with $450 \mathrm{~m}$ elevation and the following geographical coordinates: $06^{\circ} 14^{\prime} 16^{\prime \prime}$ South latitude and $42^{\circ} 41^{\prime}$ 18" West longitude. The soil, according to a Piauí state soil survey, is a YELLOW OXISSOL. The region has average annual temperature of $32{ }^{\circ} \mathrm{C}$ and average annual rainfall of $1350 \mathrm{~mm}$, with rainfall distributed from January to May (Equatorial Continental climate, with annual isohyets between 800 to $1,400 \mathrm{~mm}$ ). Climate, according to Köppen climate classification, is of Aw' type.

Four areas managed with similar morphopedological characteristics were chosen, namely: 1) Area with one year of cultivation (PC1), where the first year consisted of rice cultivation. Conventional management was applied from planting to harvest with the use of plow and harrow. PC1 received liming with dolomitic lime and NPK fertilization, according to the needs identified by soil analysis; 2) area with three years of cultivation (PC3), where succession occurred with soybean/corn/soybean crops. Fertilization, liming and soil management were identical to $\mathrm{PC} 1 ; 3$ ) area with six years of cultivation (PC6), with one year of rice cultivation and five years of soybean cultivation. Fertilization and soil management were identical to PC1; 4) Area of Native Savanna Forest (NF), used as a reference, as it is a balanced system with no human intervention history.

In each area, four georeferenced $200 \mathrm{~m}^{2}$ plots were demarcated. In these areas, soil samples were collected from 0 to $0.20 \mathrm{~m}$ and 0.20 to $0.40 \mathrm{~m}$ layers in March 2014, period with good soil moisture. For chemical and biological assessments, 10 random subsamples were removed from each plot to form a composite sample, considered as repetition. Samples collected for microbiological analyzes were packed in plastic bags with respirator and kept in a cold room at $4{ }^{\circ} \mathrm{C} \pm 1{ }^{\circ} \mathrm{C}$ until analysis. Soil texture was determined by particle size analysis using the pipette method, and results are shown in Table 1.

Table1.Particle size composition of soils in the management systems studied.

\begin{tabular}{cccccc}
\hline \multirow{2}{*}{ System } & \multicolumn{4}{c}{ Particle size $\left(\mathbf{g ~ k g}^{\mathbf{- 1}}\right)$} & \multirow{2}{*}{ Textural class } \\
\cline { 2 - 4 } & Coarse sand & \multicolumn{5}{c}{ Fine sand } & Silt & Clay & \\
\hline PC1 & 120 & Depth $(0.00-0.20 \mathrm{~m})$ \\
PC3 & 125 & 260 & 200 & 420 & Clay \\
PC6 & 142 & 200 & 240 & 418 & Clay \\
NF & 160 & 270 & 210 & 360 & Clay \\
\hline & \multicolumn{5}{c}{ Depth $(0.20-0.40 \mathrm{~m})$} \\
PC1 & 125 & 260 & 185 & 430 & Clay \\
PC3 & 120 & 214 & 206 & 460 & Clay \\
PC6 & 150 & 192 & 208 & 450 & Clay \\
NF & 138 & 230 & 170 & 462 & Clay \\
\hline
\end{tabular}

PC1: Area with a year of conventional tillage; PC3: area with three years of conventional tillage; PC6: area with six years of conventional tillage; NF: Native Savanna forest area.

Soil $\mathrm{pH}$ in water $(1: 2.5)$ was determined by potentiometry. Exchangeable acidity $\left(\mathrm{Al}^{+3}\right)$ was extracted with $\mathrm{KCl}$ mol $\mathrm{L}^{-1}$ and quantified by

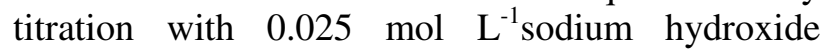
standardized by potassium biphthalate. Phosphorus and potassium were extracted with Mehlich 1 and determined by colorimetry and flame photometry, respectively. Calcium and magnesium determination were conducted through atomic absorption spectrophotometry, extracted with $\mathrm{KCl} \mathrm{mol} \mathrm{L}{ }^{-1}$. 
Microbial biomass carbon (MBC) was determined by irradiation-extraction method, proposed by Islam and Weil (1998). Total organic carbon (TOC) was determined by organic matter oxidation with potassium dichromate in the presence of concentrated sulfuric acid (Walkley-Black). From MBC and TOC content values, microbial quotient (qMIC) was calculated by the following expression: $\mathrm{qMIC}=\mathrm{MBC} / \mathrm{TOC} \times 100$.

Respiratory activity was estimated in the laboratory through quantification of the $\mathrm{CO}_{2}$ released during seven days of soil incubation in a closed system, where $\mathrm{CO}_{2}$ was captured in $\mathrm{NaOH} 1$ mol L $\mathrm{L}^{-1}$ solution and subsequently titrated with $\mathrm{HCl}$ $0.5 \mathrm{~mol} \mathrm{~L}^{-1}$. Results were expressed in $\mathrm{CO}_{2} \mu \mathrm{g} \mathrm{m}^{-2} \mathrm{~d}^{-}$ ${ }^{1}$. Metabolic quotient $\left(\mathrm{qCO}_{2}\right)$, which consists of the microbial respiration per biomass unit, was calculated and expressed in $\mathrm{CO}_{2} \mu \mathrm{g}$ biomass ${ }^{-1} \mathrm{~d}^{-1}$.

The data obtained were submitted for variance analysis (ANAVA) and test of means at a $5 \%$ level of probability. The R Statistical 7.5 beta package was used. Multivariate principal component analysis (PCA) techniques were also employed to understand how the variables interacted at the same time, using the SAS 9.0 statistical program.

\section{RESULTS AND DISCUSSION}

The highest $\mathrm{pH}$ values were found in the PC6 soil, in depths from 0.00 to $0.20 \mathrm{~m}$ and from 0.20 to $0.40 \mathrm{~m}$. In the last layer aforementioned, values were not statistically different from the PC3 soil (Table 2). Research conducted by Campos et al. (2011) in the Piauí Savanna reported that there is $\mathrm{pH}$ increase through lime addition, whether applied to the soil surface or incorporated for several years, compared to newly deforested areas and Savanna areas. In addition, there was $\mathrm{Ca}^{2+}+\mathrm{Mg}^{2+}$ increase and $\mathrm{H}^{+}+\mathrm{Al}^{3+}$ and $\mathrm{Al}^{3+}$ decrease in PC3 and PC6 areas with the longest cultivation period in relation to other areas, as also observed by Carneiro et al. (2009).

Table 2. Soil chemical and biological attributes in the management systems studied.

\begin{tabular}{|c|c|c|c|c|}
\hline & PC1 & PC3 & PC6 & NF \\
\hline \multicolumn{5}{|c|}{$0-0.20 \mathrm{~m}$} \\
\hline $\mathrm{pH}$ & $5.00 \mathrm{c}$ & $5.70 \mathrm{~b}$ & $6.08 \mathrm{a}$ & $4.34 \mathrm{~d}$ \\
\hline $\mathrm{P}\left(\mathrm{mg} \mathrm{kg}^{-1}\right)$ & $4.55 \mathrm{~b}$ & $10.35 \mathrm{a}$ & $10.02 \mathrm{a}$ & $1.75 \mathrm{c}$ \\
\hline $\mathrm{K}^{+}\left(\mathrm{cmol} \mathrm{kg}^{-1}\right)$ & $0.05 \mathrm{c}$ & $0.09 \mathrm{~b}$ & $0.18 \mathrm{a}$ & $0.04 \mathrm{c}$ \\
\hline $\mathrm{Ca}^{2+}+\mathrm{Mg}^{2+}\left(\mathrm{cmol} \mathrm{kg}^{-1}\right)$ & $2.60 \mathrm{~b}$ & $7.03 \mathrm{a}$ & $6.46 \mathrm{a}$ & $1.00 \mathrm{c}$ \\
\hline $\mathrm{Al}^{3+}\left(\mathrm{cmol} \mathrm{kg}^{-1}\right)$ & $1.52 \mathrm{~b}$ & $0.09 \mathrm{c}$ & $0.14 \mathrm{c}$ & $2.28 \mathrm{a}$ \\
\hline $\mathrm{H}^{+}\left(\mathrm{cmol} \mathrm{kg}^{-1}\right)$ & $8.13 \mathrm{a}$ & $5.63 \mathrm{~b}$ & $5.12 \mathrm{~b}$ & $6.87 \mathrm{ab}$ \\
\hline TOC $\left(\mathrm{g} \mathrm{kg}^{-1}\right)$ & $9.29 \mathrm{~b}$ & $9.09 \mathrm{~b}$ & $7.74 \mathrm{c}$ & $10.53 \mathrm{a}$ \\
\hline $\operatorname{MBC}\left(\mathrm{mg} \mathrm{kg}^{-1}\right)$ & $365.45 \mathrm{~b}$ & $316.36 \mathrm{~b}$ & $229.09 \mathrm{c}$ & $594.54 \mathrm{a}$ \\
\hline $\mathrm{QMIC}(\%)$ & $4.06 \mathrm{~b}$ & $3.47 \mathrm{bc}$ & $2.97 \mathrm{c}$ & $5.65 \mathrm{a}$ \\
\hline $\mathrm{C}-\mathrm{CO}_{2}\left(\mathrm{mg} \mathrm{CO} \mathrm{kg}^{-1} \mathrm{~d}^{-1}\right)$ & $91.30 \mathrm{~b}$ & $90.20 \mathrm{~b}$ & $102.30 \mathrm{a}$ & $112.20 \mathrm{a}$ \\
\hline$q \mathrm{CO}_{2}\left(\mathrm{~g} \mathrm{CO}_{2} \mathrm{~kg}^{-1} \mathrm{~d}^{-1}\right)$ & $0.25 \mathrm{~b}$ & $0.24 \mathrm{~b}$ & $0.44 \mathrm{a}$ & $0.18 \mathrm{c}$ \\
\hline \multicolumn{5}{|c|}{$0.20-0.40 \mathrm{~m}$} \\
\hline $\mathrm{pH}$ & $4.70 \mathrm{~b}$ & $5.83 \mathrm{a}$ & $5.98 \mathrm{a}$ & $4.94 \mathrm{~b}$ \\
\hline $\mathrm{P}\left(\mathrm{mg} \mathrm{kg}^{-1}\right)$ & $3.77 \mathrm{c}$ & $7.42 \mathrm{~b}$ & $14.62 \mathrm{a}$ & $1.76 \mathrm{c}$ \\
\hline $\mathrm{K}^{+}\left(\mathrm{cmol} \mathrm{kg}^{-1}\right)$ & $0.04 b c$ & $0.06 \mathrm{~b}$ & $0.10 \mathrm{a}$ & $0.03 \mathrm{c}$ \\
\hline $\mathrm{Ca}^{2+}+\mathrm{Mg}^{2+}\left(\mathrm{cmol} \mathrm{kg}^{-1}\right)$ & $1.68 \mathrm{c}$ & $7.54 \mathrm{a}$ & $6.21 \mathrm{~b}$ & $0.51 \mathrm{~d}$ \\
\hline $\mathrm{Al}^{3+}\left(\mathrm{cmol} \mathrm{kg}^{-1}\right)$ & $1.67 \mathrm{a}$ & $0.13 \mathrm{~b}$ & $0.09 \mathrm{~b}$ & $2.06 \mathrm{a}$ \\
\hline $\mathrm{H}^{+}\left(\mathrm{cmol} \mathrm{kg}^{-1}\right)$ & $7.70 \mathrm{a}$ & $5.90 \mathrm{~b}$ & $5.26 \mathrm{~b}$ & $6.16 \mathrm{ab}$ \\
\hline TOC $\left(\mathrm{g} \mathrm{kg}^{-1}\right)$ & $8.69 \mathrm{ab}$ & $9.17 \mathrm{a}$ & $7.26 \mathrm{c}$ & $7.90 \mathrm{~b}$ \\
\hline $\operatorname{MBC}\left(\mathrm{mg} \mathrm{kg}^{-1}\right)$ & $245.45 \mathrm{~b}$ & $252.72 \mathrm{~b}$ & $167.72 \mathrm{c}$ & $312.00 \mathrm{a}$ \\
\hline $\mathrm{QMIC}(\%)$ & $2.5 \mathrm{~b}$ & $2.75 \mathrm{bc}$ & $2.31 \mathrm{c}$ & $3.97 \mathrm{a}$ \\
\hline $\mathrm{C}-\mathrm{CO}_{2}\left(\mathrm{mg} \mathrm{CO} \mathrm{Cg}^{-1} \mathrm{~d}^{-1}\right)$ & $79.0 \mathrm{a}$ & $68.20 \mathrm{~b}$ & $81.40 \mathrm{a}$ & $86.90 \mathrm{a}$ \\
\hline$q \mathrm{CO}_{2}\left(\mathrm{~g} \mathrm{CO}_{2} \mathrm{~kg}^{-1} \mathrm{~d}^{-1} \mathrm{CBM}\right)$ & $0.32 \mathrm{~b}$ & $0.27 \mathrm{~b}$ & $0.45 \mathrm{a}$ & $0.28 \mathrm{~b}$ \\
\hline
\end{tabular}

PC1: Area with a year of conventional tillage; PC3: area with three years of conventional tillage; PC6: area with six years of conventional tillage; NF: Native Cerrado forest area. Means followed by the same letter are not statistically different by t-test at $5 \%$ probability.

There was significant $\mathrm{K}^{+}$increase with time of use due to yearly fertilization, practice that gradually improves the fertility of Savanna soils, usually dystrophic. The PC6 system showed higher $\mathrm{K}^{+}$values in two depths, as this area had received potassic fertilizers for six years in a row, although 
soil $\mathrm{K}^{+}$content was only classified as average (70 $\mathrm{mg} \mathrm{dm}^{-3}$ ), according to classification of Savanna soils for annual crops. Other authors, in studies on chemical properties of Savanna OXISSOL management conventionally, also found average $\mathrm{K}^{+}$ values in areas cultivated for prolonged periods (MATIAS et al., 2009; SOUZA; ALVES, 2003). According to Bernadi et al. (2009), high solubility of potassium salts (commonly used) leads to high losses by leaching, which can be minimized through split fertilization.

$P$ availability in the soil differed between systems. The area with the longest time of use (PC6) showed higher levels in the two layers studied. However, despite annual P fertilization, results have only fitted within the average for clay soils (ALVAREZ et al., 1999). It is known that these soils have high $\mathrm{P}$ adsorption capacity with clay particles due to mineralogy formed by minerals in advanced weathering stage, usually requiring large amounts of phosphate fertilizers (SOUZA; LOBATO, 2004). Typically, lower phosphorus contents are observed in systems with intensive soil tillage compared to no-tillage. This is due to, among other factors, fertilizer dilution during soil tillage with disc harrowing, which makes the fertilizer react with a larger soil layer, providing lower P levels capable of being extracted (NUNES et al., 2011). In general, the PC1 system showed fertility levels similar to those of the forest area, as Savanna OXISSOL require a longer time for chemical attributes to reach satisfactory levels (SOUZA; ALVES, 2003).

Organic carbon (OC) ranged from 7.26 to $10.53\left(\mathrm{~g} \mathrm{~kg}^{-1}\right)$ (Table 2). The OC loss due to management practices involving annual crops with heavy soil tillage (plowing and harrowing) can only be identified years after tillage periodic use (VIANA et al., 2011), as can be observed through lower levels shown in the PC6 area compared to the other areas.

Soil preparation by conventional management contributes to organic matter decrease and accelerates mineralization, as aggregates are broken by harrow discs during soil mixing. Thus, organic matter, which was once physically protected, is exposed to the attack of soil microorganisms, reducing soil OC content (IBIAPINA et al., 2014; RAMOS et al., 2011). There is temporary stimulus of microbiota after soil disturbance due to better aeration conditions, higher temperatures and more alteration between soil wetting and drying, accelerating organic matter decomposition, as also observed by Marchiori Junior and Melo (2000).
Studies by Cerri et al. (2011) found C reductions of $38 \%$ and $46 \%$ in the soil layer from0 to 0.20 matter 12 and 50 years of sugar cane intensive conventional tillage, respectively. In turn, Alvarez et al. (1995) showed that soils with 12 years of cultivation under conventional tillage had organic matter (OM) content decrease of $50 \%$ in the first $0.05 \mathrm{~m}$ of depth and of up to $8 \%$ in the first $0.20 \mathrm{~m}$ above the ground in relation to the management that kept residue addition, as also observed in this study.

On the other hand, the Savanna is a tropical forest in which a ground vegetation, consisting mainly of grasses that coexist with trees and sparse shrubs, can provide organic residues with several substrates of distinct organic and nutritional quality. Therefore, plant litter quantity and quality is influenced, contributing to $\mathrm{CO}$ increase in this environment.

Regarding microbial biomass carbon (MBC) and taking the system with native Savanna vegetation as reference, reductions of 39, 47 and $62 \%$ were observed in the soil layer from 0 to 0.20 $\mathrm{m}$, and of 22,19 and $46 \%$ in the soil layer from 0.20 to $0.40 \mathrm{~m}$ for PC1, PC3 and PC6 treatments, respectively. As also observed by other authors (CARNEIRO et al., 2009; CHAER; TOTOLA, 2007), these results show that microbial biomass is more sensitive than total organic matter to the changes caused by land use. In addition, the results also indicate adverse effect of conventional planting adoption time in MBC.

It is known that microbial biomass $\mathrm{C}$ variation sand its activity are directly related to organic $\mathrm{C}$ variations in the soil (LISBOA et al., 2012). Therefore, systems which contribute to OM increase, such as Native Forest, contribute to MBC increase. Conversely, crop residues are placed in closer contact with the soil in the PC system regarding preparation method, besides favoring the disruption of aggregates, exposing OM protected fractions. Due to these factors, there is temporary microbiota stimulus after soil disturbance, accelerating organic matter decomposition, as noted in PC1 and PC3.

According to Balota et al. (1998), conventional soil preparation management promotes microbial activity reduction with preparation time in relation to carbon losses. This is due to the growing energy demand of the microbial population that is being adapted to new conditions and due to organic residue addition reduction. Thus, it is possible to native microorganisms to not be adapted to the new rhizosphere environment (LYNCH; WHIPPS, 1990). In turn, D'Andrea et al. (2002), while studying biological indicators of quality in a RED 
OXISSOL, found major MBC differences in the surface layer $(0-0.20 \mathrm{~m})$. In addition, native Savanna had higher microbial carbon values (1.310 $\mathrm{mg} \mathrm{kg}{ }^{-1} \mathrm{C}$ ) in relation to management systems with long-term conventional tillage.

Furthermore, liming was conducted to correct soil acidity in the cultivated areas, and alkalinity may have favored the development of a population of rapid growth colonizing organisms (SAKAMOTO; OBA, 1994), generating lower diversity and energy use imbalance in this management system. High microorganism diversity is generally associated with high community stability, where each population plays a functional role that determines the normal maintenance of matter and energy flows in each trophic level of a particular ecosystem (CHAER; TÓTOLA, 2007). However, according to the authors, the microorganism population known as "K" strategists depends on physiological adaptations to the carrying capacity of the environment where they live, and their populations tend to be more stable.

The qMIC ratio showed the same behavior of microbial biomass, i.e., native forest showed higher values, which decreased according to land use time. Some authors suggest that higher chemical diversity of organic matter favors organisms that have a more economic metabolism. Thus, less $\mathrm{C}$ of an organic substrate would be channeled to the energy metabolism and more $\mathrm{C}$ would be fixed in the microbial cells, affecting the microbial $\mathrm{C}$ : organic C ratio (CHAER; TÓTOLA, 2007). Furthermore, in a situation in which biomass under goes some stress factor (nutrient deficiency, acidity, etc.), C use capacity is decreased and qMIC also decreases (WARDLE, 1994).

Soils located in PC3 and PC6 areas had the lowest qMIC values. The lowest qMIC values demonstrate the adverse effect of prolonged conventional management to this indicator of soil quality, corroborating results of Ramos et al., (2011), who found a strong and lasting effect of monocultures with heavy machine use on soil microbial communities. In PC1, PC3 and PC6 systems, vegetation removal excluded organic material entry in both shoot and root system, which determined environmental un balance and contributed to qMIC decrease. Thus, in preserved and balanced environments, this ratio value can be used as a standard to evaluate how much a soil is degraded.

The highest respiratory activity values were found in Savanna forest and CT6 soils in the layers from 0 to $0.20 \mathrm{~m}$ and from 0.20 to $0.40 \mathrm{~m}$ (Table 2), which could indicate higher energy balance in those systems. Thus, the highest basal respiration values $\left(\mathrm{C}-\mathrm{CO}_{2}\right)$ found in the native area can be related to dense plant litter and the large amount of roots, which release exudates and act as an energy source, stimulating higher soil respiration $\left(\mathrm{C}-\mathrm{CO}_{2}\right)$, mainly in the surface layers, according to a study conducted in Savanna areas (ARAÚJO et al., 2007).

However, data cannot be explained by the management type applied in the areas and seem to reflectrandom variations of factors such as plant litter presence, humidity and temperature. Therefore, it is important to consider the respiration rate per biomass unit, which was the metabolic quotient $\left(\mathrm{qCO}_{2}\right)$ in this case, in soil quality studies. In some cases, differences between degraded and preserved soils are not detected when only respiration is assessed.

In the native Savanna vegetation, $\mathrm{qCO}_{2}$ had the lowest value, while the PC6 management system had the highest value in the depth between 0 and $0.20 \mathrm{~m}$. These results also show the disturbance caused by conventional tillage on microbial biomass after six years of use, which reflects in low microorganism efficiency to convert organic residue into microbial biomass, as much of residues are mineralized and returned to the atmosphere in $\mathrm{CO}_{2}$ form. Research by Porto et al., (2009) and Jakelaitis et al. (2008) showed that the microorganism population in monoculture soils needs higher energy requirement for its maintenance than the population in native Savanna soils, or soil sthat are not subjected to stress.

Metabolic quotient $\left(\mathrm{qCO}_{2}\right)$ allows for the identification of soils containing the most efficient biomass regarding carbon and energy use, and the environment with the lowest degree of disturbance or stress, where there is organic production surplus in relation to respiration. These parameters are in accordance with the "Ecosystem Bioenergy Development" theory by Odum (1969), which emphasizes that microorganisms can greatly vary their metabolic rate depending on environmental conditions.

Principal component analysis (PCA) was conducted with a data matrix consisting of 12 variables (Figure 2). In the figure, Factor 1, formed by $\mathrm{CP} 1$ and $\mathrm{CP} 2$, and the variability retained in these two components explained $81.23 \%$ of the original variability, where $\mathrm{CP} 1$ and $\mathrm{CP} 2$ retained $63.35 \%$ and $17.88 \%$ of variability, respectively (Figure 2). 


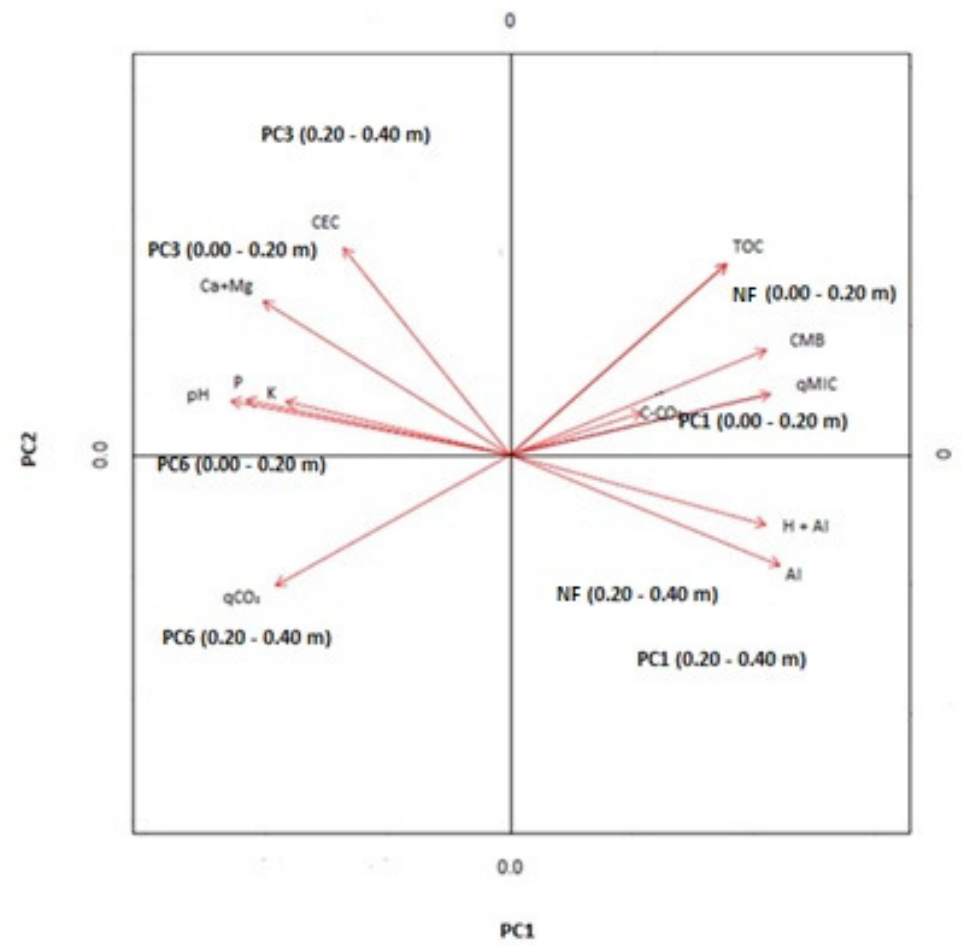

Figure 1. Variable behavior in principal component analysis: total organic carbon (TOC), microbial biomass carbon $(\mathrm{MBC})$, microbial quotient $(\mathrm{qMIC})$, basal respiration $\left(\mathrm{C}-\mathrm{CO}_{2}\right)$, metabolic quotient $\left(\mathrm{qCO}_{2}\right)$ and cation exchange capacity (CEC).

PC1: Area with a year of conventional tillage; PC3: area with three years of conventional tillage; PC6: area with six years of conventional tillage; NF: Native Cerrado forest area. Means followed by the same letter are not statistically different by t-test at $5 \%$ probability.

Interpretation of this diagram shows that the PC6 system formed an isolated group in the surface layer, positioning in the lower left quadrant, associated with metabolic quotient, which confirms the stress situation imposed by food limitation to the microorganisms in this system, as they consumed more energy for maintenance. The group formed by PC6 $(0-0.20 \mathrm{~m})$ and PC3 correlated with chemical attributes related to soil fertility and essential elements in both depths, as these areas had been receiving fertilization for a longer period.

In turn, the Savanna forest area and PC1 system in the surface layer formed a group in the upper right quadrant that was related to biological attributes (MBC, respiration, qMIC and $\mathrm{OC}$ associated with organic matter content. Finally, these same areas in the subsurface layer formed a group, which was related to chemical attributes associated with soil acidity.
The Savanna forest includes plant residue maintenance in the soil surface and provides a more favorable environment for biota development due to high organic matter content. In this case, the PC1 system still had an organic matter reserve, showing close results to those of the forest in this variable. Similarly, Savanna soils show low base saturation and high acidity. Thus, the PC1 system, even after fertilization, was still far from the optimum range of nutrient levels, which is more associated with NF.

\section{CONCLUSIONS}

The variables studied were effective as soil quality indicators.

Conventional management time of use influenced negatively changes in soil microbiological properties.

Systems with longer times of use showed a better soil chemical quality in both studied depths.

RESUMO: A produção agrícola brasileira vem se destacando nos solos sob Cerrado devido aos ganhos significantes na produção e produtividade nessas áreas. Neste trabalho, objetivou-se avaliar as alterações nos indicadores químicos e biológicos do solo em áreas de Cerrado piauiense com 1 (PC1), 3 (PC3) e 6 (PC6) anos manejadas sob plantio convencional, em relação a uma mata nativa (MN) de Cerrado usada como controle. Foram avaliados atributos químicos $\left(\mathrm{pH}, \mathrm{P}, \mathrm{Ca}^{2+}, \mathrm{Mg}^{2+}, \mathrm{K}^{+}, \mathrm{H}^{+}, \mathrm{Al}^{3+}\right.$ e carbono orgânico) e microbiológicos (carbono da biomassa microbiana, respiração 
basal, quociente microbiano e quociente metabólico). Nas áreas PC6 e PC3 foram observados, em todas as camadas avaliadas, redução dos teores de $\mathrm{Al}^{3^{+}} \mathrm{e}^{+}+\mathrm{Al}^{3+}$ e carbono orgânico total, e aumento do $\mathrm{pH}$ e teores dos nutrientes em relação aos demais sistemas. O COT mostrou-se pouco sensível com o tempo, visto que a mudança foi gradual conforme o uso do solo. Os valores de CBM e qMIC foram mais elevados no solo sob vegetação natural, indicando a ocorrência de efeitos adversos de monocultura manejada em sistema plantio convencional prolongado sobre essas variáveis. O solo sob PC6 mostrou o maiores valores de $\mathrm{qCO}_{2}$ nas profundidades de 0 a 0,20 e de 0,20 a 0,40 m que demonstra a baixa eficiência dos microrganismos em converter os resíduos orgânicos em biomassa microbiana neste sistema. O manejo convencional utilizado potencializou a perda de qualidade biológica do solo desses sistemas e favoreceu os atributos químicos com o tempo de uso.

PALAVRAS-CHAVE: Plantio convencional. Degradação. Soja. Cerrado.

\section{REFERENCES}

ALVAREZ V., V. H.; NOVAIS, R. F.; BARROS, N. F.; CANTARUTTI, R. B.; LOPES, A. S. Interpretação dos resultados das análises de solos. In: RIBEIRO, A.C.; GUIMARÃES, P. T. G.; ALVAREZ V., V. H. (Ed.) Recomendações para o uso de corretivos e fertilizantes em Minas Gerais $\mathbf{-} \mathbf{5}^{\mathbf{a}}$ Aproximação. Viçosa, MG: Comissão de Fertilidade do Solo do Estado de Minas Gerais, 1999, p. 25-32. https://doi.org/10.1007/BF00336164

ALVAREZ, R.; SANTANATOGLIA, O. J.; GARCIA, R. Effect of temperature on soil microbial biomass and its metabolic quotient in situ under different tillage systems. Biology Fertility of Soils, Berlin, v. 19, p. 227230, 1995.

ARAGÃO, D. V.; CARVALHO, C. J. R.; KATO, O. R.; ARAÚJO, C. M.; SANTOS, M. T. P.; MOURÃO JÚNIOR, M. Avaliação de indicadores de qualidade do solo sob alternativas de recuperação do solo no Nordeste Paraense. Acta Amazônica, Manaus, v. 42, n. 1, p. 11-18, 2012. https://doi.org/10.1590/S004459672012000100002

ARAÚJO, R.; GOEDERT, W. J.; LACERDA, M. P. C. Qualidade de um solo sob diferentes usos e sob cerrado nativo. Revista Brasileira de Ciência do Solo, Viçosa, v. 31, n. 5, p. 1099-1108, 2007.

BALOTA, E. L. COLOZZI-FILHO, A; ANDRADE, D. S; HUNGRIA, M. Biomassa microbiana e sua atividade em solos sob diferentes sistemas de preparo e sucessão de culturas. Revista Brasileira de Ciência do Solo, Viçosa, v. 22, n. 4, p. 641-649, 1998.

BERNARDI, A. C. C.; OLIVEIRA JÚNIOR, J. P.; LEANDRO, W. M.; MESQUITA, T. G. S.; FREITAS, P. L.; CARVALHO, M. C. S. Doses e formas de aplicação da adubação potássica na rotação soja, milheto e algodão em sistema plantio direto. Pesquisa Agropecuária Tropical, Goiânia, v. 39, n. 2, p. 158-167, 2009.

CAMPOS, L. P.; LEITE, L. F.C.; MACIEL, G. A.; IWATA, B. F.; NOBREGA, J. C. A. Atributos químicos de um Latossolo Amarelo sob diferentes sistemas de manejo. Pesquisa Agropecuária Brasileira, Brasília, v. 46, n. 12, p. 1681-1689, 2011. https://doi.org/10.1590/S0100-204X2011001200014

CARNEIRO, M. A. C.; SOUZA, E. D.; REIS, E. F.; PEREIRA, H. S.; AZEVEDO, W. R. Atributos Físicos, Químicos e Biológicos de Solo de Cerrado sob Diferentes Sistemas de uso e Manejo. Revista Brasileira de Ciência do Solo, Viçosa, v. 33, n. 1, p. 147-157, 2009.

CERRI, C. C., GALDOS, M. V., MAIA, S. M. F., BERNOUX, M., FEIGL, B. J., POWLSON, D., CERRI, C. E. P. Effect of sugarcane harvesting systems on soil carbon stocks in Brazil: an examination of existing data. European Journal of Soil Science, Londres, v. 62, n. 1, p. 23-28, 2011. https://doi.org/10.1111/j.13652389.2010.01315.x 
CHAER, G. M; TOTOLA, M. R Impacto do Manejo de Resíduos Orgânicos Durante a Reforma plantios eucalipto SOBRE Indicadores Qualidade solo. Revista Brasileira de Ciência do Solo, Viçosa, v. 31, n. 6, p. 1381-1396, 2007.

D’ANDRÉA, A. F.; SILVA, M. L. N.; CURI, N. O.; SIQUEIRA, J. O.; CARNEIRO, M. A. C. Atributos biológicos indicadores da qualidade do solo em diferentes sistemas de manejo do solo na região do cerrado no sul do Estado de Goiás. Revista Brasileira de Ciência do Solo, Viçosa, v. 26, n. 4, p. 913-923, 2002.

IBIAPINA, T. V. B.; SALVIANO, A. A. C.; NUNES, L. A. P. L.; MOUSINHO, F. E. P. ; LIMA, M. G. ; SOARES, L. M. S . Resistência à penetração e agregação de Latossolo Amarelo sob monocultivo de soja e de eucalipto no cerrado piauiense. Cientifica, Jaboticabal, v. 42, n. 4, p. 411-418, 2014.

ISLAM, K.R.; WEIL, R. R. A rapid microwave digestion method for colorimetric measurement of soil organic carbon. Communication Soil Science Plant Analitical, New York, v. 29, n.12, p. 2269 - 2284, 1988.

JAKELAITIS, A.; SILVA, A. A.; SANTOS, J. B.; VIVIAN, R. Qualidade da camada superficial de solo sob mata, pastagens e áreas cultivadas. Pesquisa Agropecuária Tropical, Goiânia, v. 38, n. 2, p. 118-127, 2008.

LISBOA, B. B.; VARGAS, L. K.; SILVEIRA, A. O.; MARTHINS, A. F.; SELBACH, P. A. Indicadores microbianos de qualidade do solo em diferentes sistemas de manejo. Revista Brasileira de Ciência do Solo, Viçosa, v. 38, n. 1, p. 45-55, 2012.

LYNCH, L. M.; WHIPS, J. M. Substrate flow in the rhizosphere. Plant Soil, The Hague, v. 29, n. 1, p. 1-10, 1990. https://doi.org/10.1007/BF00011685

MARCHIORI JÚNIOR, M.; MELO, W. J. Alterações na matéria orgânica e na biomassa microbiana em solo de mata natural submetido a diferentes manejos. Pesquisa Agropecuária Brasileira, Brasília, v. 35, n. 6, p. 1177-1182, 2000. https://doi.org/10.1590/S0100-204X2000000600014

MATIAS, M. C. B. S.; SALVIANO, A. A. C.; LEITE, L. F. C.; ARAUJO, A. S. F. Biomassa microbiana e estoques de $\mathrm{C}$ e $\mathrm{N}$ do solo em diferentes sistemas de manejo, no cerrado do Estado do Piauí. Acta Scientiarum Agronomy, Maringá, v. 31, n. 3, p. 517-521, 2009.

NUNES, R. S.; LOPES, A. A. C.; SOUSA, D. M. G.; MENDES, I. C. Sistemas de manejo e os estoques de carbono e nitrogênio em Latossolo de Cerrado com a sucessão soja-milho. Revista Brasileira de Ciência do Solo, Viçosa, v. 35, n. 4, p. 1407-1419, 2011.

ODUM, E. P. The strategy of ecosystem development. Science, Washington, v. 164, n. 3877, p. 262-270, 1969. https://doi.org/10.1126/science.164.3877.262

PETTER, F.A., SILVA J.A., PACHECO, L.P., ALMEIDA, F.A., ALCÂNTARA NETO, F., ZUFFO, A.M. Desempenho agronômico da soja a doses e épocas de aplicação de potássio no cerrado piauiense. Revista de Ciências Agrarias, Manaus, v.55, n.3, p.190-196, 2012. https://doi.org/10.4322/rca.2012.057

PÔRTO, M. L.; ALVES, J. DO C.; DINIZ, A. A.; SOUZA, A. P.; SANTOS, D. Indicadores biológicos de qualidade do solo em diferentes sistemas de uso no Brejo Paraibano. Ciência \& Agrotecnologia, Lavras, v. 33, n. 4, p. 1011-1017, 2009.

RAMOS, F. T.; NUNES, M. C. M.; CAMPOS, D. T. S.; RAMOS, D. T.; MAIA, J. C. S. Atributos físicos e microbiológicos de um latossolo vermelho-amarelo distrófico típico sob cerrado nativo e monocultivo de soja. Revista Brasileira de Agroecologia, Pelotas, v. 6, n. 2, p. 79-91, 2011.

SAKAMOTO, K.; OBA, Y. Effects of fungal to bacterial ratio on the relationship between $\mathrm{CO} 2$ evolution and total soil microbial biomass. Biology and Fertility of Soils, Florença, v. 17, n. 1, p. 39-44, 1994. 
SOUSA, D. M. G.; LOBATO, E. Cerrado: Correção do Solo e a adubação. $2^{\circ}$ Ed. Brasília: Embrapa Informação Tecnológica, 2004, 416 p.

SOUZA, Z. M.; ALVES, M. C. Propriedades químicas de um Latossolo Vermelho distrófico de Cerrado sob diferentes usos e manejos. Revista Brasileira de Ciência do Solo, Viçosa, v. 27, n. 1, p. 133-139, 2003.

VIANA, E. T.; BATISTA, M. A.; TORMENA, C. A.; COSTA, A. C. S.; INOUE, T. T. Atributos físicos e carbono orgânico em Latossolo Vermelho sob diferentes sistemas de uso e manejo. Revista Brasileira de Ciência do Solo, v. 35, n. 6, p. 2105-2114, 2011. https://doi.org/10.1590/S0100-06832011000600025

WARDLE, D. A. Metodologia para quantificação da biomassa microbiana do solo. In: HUNGRIA, M.; ARAUJO, R. S. (Ed.) Manual de métodos empregados em estudos de microbiologia agrícola. Brasília: Embrapa, 1994, p. 419-436. 